\title{
Islamic Microfinance and Sustainable Development Goals in
}

\section{Bangladesh}

\author{
Md. Harun Ur Rashid ${ }^{1}$, Mohammed Jashim Uddin ${ }^{1} \&$ Shah Asadullah Mohd. Zobair ${ }^{1}$ \\ ${ }^{1}$ International Islamic University Chittagong (IIUC), Bangladesh \\ Correspondence: Md. Harun Ur Rashid, Dept. of Economics \& Banking, IIUC, Tel: +8801928953050, \\ Email:harunais88@gmail.com
}

Received: May 23, 2018

Accepted: May 30, 2018

Online Published: June 6, 2018

\begin{abstract}
The main objective of this study is to explore the Islamic Microfinance Instruments in achieving the Sustainable Development Goals (SDGs) in Bangladesh. The methodology of this study is based on secondary data including existing relevant literature, and annual reports of different financial institutions. The findings of this study show that Islamic microfinance institutions have a broader scope to attain SDGs through their various investment modes.The study categorizes the Islamic microfinance instruments into four broadly parts which are profit and loss sharing financing, non-profit \& loss sharing financing, Islamic social enterprise based financing and charity based financing which have a positive effect to the real sector of the sustainable economy that will lead towards achieving SDGs. The Islamic Microfinance institutions are continuing their efforts in attaining SDGs through their various products. With growing the potentiality, Islamic microfinance has both direct and indirect impacts on ensuring economic development, environmental sustainability, and social inclusion by creating employment opportunity, spreading knowledge and skills, making self-dependent, protecting from adverse effects. The paper also tries to put recommendations to reduce the challenges of Islamic microfinance acting as impediments to achieving the SDGs.
\end{abstract}

Keywords: Islamic Microfinance (IMF), Islamic Microfinance Institutions (IMFIs), Sustainable Development Goals (SDGs), Bangladesh.

\section{Introduction}

A shift of relationship between people and nature regarding enhancement of humanity results the need and concept of sustainable development (Hopwood, Mellor, \& O'Brien, 2005). Sustainable Development can be defined as the state of the world which can be attained by combining local and global effort to meet the needs of human being with the activities that will ensure the safety of the society and environment of future generation (Kates, Parris, \& Leiserowitz, 2005). For ensuring a world with sustainable development, UN declared Sustainable Development Goals (SDGs) in 2014. UN declared 17 goals to be achieved in 2030 to ensure sustainable devolvement. SDGs are the successor to the MDGs which were expected to be achieved within 2015. Throughout the world, countries are planning and using different types of tools to achieve SDGs. In this instance, the talk regarding the sense of Islamic Micro Finance Tools is getting huge attention since these tools are based on the principles that are consistent with the well-being of humanity. Islamic microfinance tools contributed a lot to attain MDGs successfully in the economy having the existence of such tools. The contribution of microfinance in achieving SDGs through alleviating poverty and generating employment is recognized globally. But among 
these tools, debt based tools are facing some problems compared to equity-based financing tools. Islamic micro financial tools are mainly equity-based which are making more sense than conventional debt-based financing tools. Islamic Micro Finance tools are sheltered by Islamic Principles having the only motto to ensure the equity and justice in wealth distribution to result in hunger, suppression and poverty free world which is very consistent with the motto of SDGs. It is proven that financial structures having Islamic financial institution are more focused on social development. As a Muslim country, lots of Islamic financial institutions are working in Bangladesh and helping ensure sound economy. This study tries to explore the roles of Islamic microfinance in achieving SDGs in Bangladesh.

This study has been structured into six chapters. Following the introduction, the second chapter contains literature review; the third and fourth chapter deal with objectives and methodology of the study respectively. The fifth chapter analyzes the results exploring the contribution of IMFIs in achieving SDGs; and the last section points out the implications, limitations and puts recommendations finally.

\section{Literature Review}

Though Bangladesh has recently entered into the list of developing country and made a perspective plan termed as 'Vision 2021' which aim is to enhance the sustainability, it is struggling against poverty as the present poverty rate is $31.5 \%$. In spite of conducting some researchers work regarding the significance of Islamic finance tools in attaining SDGs and MDGs, it is still mentionable to explore the contributions of IMFIs towards the development of Bangladeshi economy.

Dhaoui (2015) argued that in Bangladesh Islamic Financial Institutions are significantly playing the role to alleviate poverty. In Bangladesh, IFIs are designing their service in the way that enhances the access of poor people which increase saving and income. He suggested IFIs to lunch branches in a remote area and considers local people irrespective of gender to be hired to serve and educate poor people. He also suggested for group lending for reducing the risk of default. Lawal and Imam identified that implementation of MDG achieved noticeable progress towards addressing major problems of Nigeria like high poverty level, the infrastructural deficit. But some issues are exiting in severe magnitude which might be reduced to the minimum as the result of achieving SDGs. The success of achieving SDGs can be maximized with the use of Islamic financial instruments which has some features that are very consistent with attaining of SDGs. The replacement of debt financing by equity financing, used by IFIs may result in better stability of the financial sector (Buiter \& Rahbari, 2015).

A. S. Usman and Tasmin (2016a) demonstrated the role of Islamic Micro-finance in flourishing poor people's capabilities from the perspective of skills and knowledge to make them financially independent which result in more empowerment. Al Mamun, Adaikalam, and Abdul Wahab (2012) pointed out the Islamic micro-finance tools flourish the human capabilities and capital which ultimately results in human wellbeing. Both of them identified these tools as tremendously useful to ensure the existence of inclusive growth of marginal people of the economy.

Mentioning the challenges regarding future sustainability of the activities of the local organization and International NGOs who are working for the alleviation of poverty, Mohiuddin (2017) proposed on the Islamic social enterprises to ensure long-run sustainability. He distinguished between social philanthropy and social enterprise and criticized the current system of Islamic Social Enterprise Practice in Muslim Country arguing the use of Zakah is not complying with the Islamic rules. He requested the more government involvement to enhance the Islamic social enterprise to alleviate the poverty. Ahmed, Mohieldin, Verbeek, and Aboulmagd (2015) demonstrated, also, Islamic Finance principles are a blessing to ensure an inclusive and less vulnerable financial system which results in financial stability and showed confidence about Islamic Finance to attain SDGs.

The significance of Islamic Banking system is contributing to the economic development in Bangladesh. The 
massive part of the country is still unbanked which can be served by Islamic microfinance since the banking based on Islamic principles has been got popularity there (Bank, 2014). Uddin and Barai (2016) dictated that though conventional microfinance role is efficient in poverty alleviation than IFIs but less acceptable in Muslim country. For this reason, they suggested the use of Islamic Micro Finance tools, which are contributing people, to enhance their earning capabilities which result in poverty alleviation.

Though Islamic financial instruments are used very significantly throughout the Muslim world including Bangladesh, there is no theoretical framework of Islamic microfinance in achieving SDGs. The study, therefore, proposes a conceptual model along with exploring the contributions in achieving SDGs to fill up the gap.

\section{Research Objectives}

This study main aims to explore whether the Islamic microfinance institutions are contributing in achieving SDGs in Bangladesh. Other objectives included in this study are: (a) to identify the Islamic microfinance instruments through which Islamic financial institutions are contributing to achieving SDG; (b) to show the progressive scenario and performance of Islamic Microfinance Institutions in Bangladesh; (c) to explore more investment schemes are specially taken by IBBL as Islamic microfinance tools; (d) to show the role of Islamic microfinance institutions in achieving SDGs; and (e) to put policy implication and recommendation to accelerate in attaining SDGs.

\section{Research Methodology}

The study uses the secondary source to collect the required information to achieve the objectives of the study. The secondary source consists of previous articles on SDGs and Islamic microfinance institutions' investment schemes, research workings paper, the annual report of different IFIs and report and documents of various international organizations. The study also tries to frame a conceptual model based on existent literature.

\section{Data Analysis and Interpretation}

\subsection{Islamic Microfinance Approach and its Instruments}

The previous studies ensured that the leading causes of microcredit default are the diversion of loan for consumption purpose, meeting up emergencies and high-interest rate which lead the loan recipients toward taking more loans at high interest to repay the initial credits. This process makes them bound to sell their assets and retard of getting out of poverty (A. R. ABDUL RAHMAN, 2007; Laila, 2010; Parveen, 2009; A. S. Usman \& Tasmin, 2016a). Islamic Micro-finance is a market niche that develops to provide financial mediation with emphasis on ethical and moral values in business as preserved in the Quran and Hadith (teachings of Prophet Muhammad, peace be upon him) (Akhter, Akhtar, \& Jaffri, 2009; Bhuiyan, Siwar, Ismail, \& Talib, 2011). To achieve the SDG through IMF, this study identified two broad approaches to the role of Islamic microfinance institutions. They are Islamic microcredit approach and Islamic social enterprise approach.

Group-based microcredit program has formed the Islamic microfinance institutions. Group-based microcredit model is the process of opportunity for peer lending, peer monitoring, homogenous matching, and joint liability with credit risk between the group members (Bhuiyan, Siwar, \& Rashid, 2011; Dossey, 2007; Fernandez, 2010; Hassan \& Tufte, 2001; Karim, 2008).

The main difference between conventional microcredit and Islamic microcredit is the presence of Riba (interest) which is strictly prohibited in Quran (Davis \& Venkatesh, 2004) and Hadith since it embodies exploitations and oppression. Therefore, Islamic Microcredit models are developed according to Sharia ruling for finance. The following are some of the examples of Islamic Microcredit (Ahmed, 2004; Akhter et al., 2009; Khan \& Phillips, 2010; Obaidullah \& Khan, 2008).

Islamic microcredit is the small loan offered by the microcredit institutes under Shariah compliance. Islamic 
principles of management handle the financial products, and ownership structure where dealing with interest is strictly prohibited (Uddin \& Barai, 2016). A. S. Usman and Tasmin (2016b), however, showed the structure of Islamic microfinance categorizing three:

- Microcredit consists of an interest-free loan and Murabaha, lease, salam;

- Micro-equity includes Murabaha and Musharaka;

- And charity indicates. Zakat, sadaka, and waqaf.

\subsubsection{Profit \& Loss (PLS) Sharing Financing}

Profit \& loss sharing financing based on equity and participation have a strong relationship to the real economics which lead to an equitable distribution of income and wealth and assist in allocating resources efficiently (Hussain, Shahmoradi, \& Turk, 2016). Mamun, Uddin, and Islam (2017) identified two forms of PLS financing, i.e., mudaraba and musharaka whereas Dhaoui (2015) added three more products Musuqat (Orchard financing), Muzar'ah (Share of harvest) and direct investment with mudaraba and musharaka in his model.

- Mudaraba: It is such a mode where the financer invests funds in the entrepreneur business with an agreement to share profit or lose among themselves. If the business makes any profit, the profit will be distributed to them by contract. But if it makes any loss, the financer will bear the loss of his capital, and the entrepreneur takes the loss of time and labor.

- Musharaka: In this mode, both the entrepreneur and the financer contribute to the capital as well as managerial efforts by agreed upon amounts and they share profit and losses as agreed.

\subsubsection{Non Profit \& Loss Sharing Financing}

The non-PLS sharing finance is used to provide financing fund to the consumer and corporate credit. It includes the instrumentsmurâbaha, ijärah, salam, and istisna (Hussain et al., 2016).

- Murabaha: Murabaha is a trade with markup 'buy-resell' used for purchasing goods and assets on credit. Under this contract, the microfinance program, the financer buys products and resells to the microenterprises for the cost of goods plus a markup of the administrative fee. The borrower will pay for the goods in equal installments until the last payment.

- Ijara: Ijara is a lease based contract where the leaser sells the right to the lessee of using a physical asset for a specified period. During the contract period, if the lessee fails to pay, the leaser can repossess the asset as he owns the leased asset.

- Salam: Bai-Salam is also a contract of sale in which payment is made in advance by the buyer, and the delivery of the goods is a prolonged time in the future by the seller (Obaidullah \& Khan, 2008).

- Istisna: It is both parties in future will bear a spot contract between the user and manufacturer who transfer goods to clients and the obligation. There may have a third party, i.e., bank acting as an intermediary who agrees to receive payment from clients and make progress installments to the manufacturer.

\subsubsection{Islamic Social Enterprise Based Financing}

From the viewpoint of lack of available funds, the long-term sustainability of IMF institutions is a problem due to the insufficient diversification of financing modes as most of them are Murabaha-centric. In addition to it, PLS is rarely used, though it is considered as ideal. Some zakah, Awqaf and card al-Hasana based IMF institutions are being considered as potential (R. Abdul Rahman \& Dean, 2013). 
The concept of Islamic social enterprise has been received from social-business concept promoted by Nobel Laureate, Muhammad Yunus. As the primary purpose of it is not profit maximization, it has been popular and focused on social justice providing health care, accommodation as well as protecting environmental degradation.

The Islamic social enterprises may be formed based on zakah, and card al-Hasana into three categories, i.e., Awqaf based trustees and zakat based.

- Awqaf Based Financing: It includes different types of trustees based institutions such as schools, colleges, universities, hospitals or financial institutions which have a board of trustees regulated by shari'ah rules with permission of the competent authority, e.g., government. The primary source of funds may be receipt of donations from various sources such as rich people of the society, public, private or foreign aids in any kind, e.g., cash, land, building or any other fixed assets. It helps by providing education, medical treatment at the low cost to the more impoverished section of people, vocational training for unemployed youth and interest-free loans and assisting orphan and destitute women.

- Zakat Based Financing: Zakat based financing may include non-government organizations like Muslim Aid Bangladesh utilizes zakat improves the beneficiaries' livelihood by providing training facilities, loans as well as establishing income generating business. Similarly, Center for Zakat Management (CZM) also offers small Qard al-Hasana loans to improve the livelihood of the more impoverished section of the society. The IMF institutions charge a flat 9-10\% on its loans while conventional microfinance institutions charge $12.5 \%$ interest at starting which ultimately reaches $27-30 \%$ (Mohiuddin, 2017).

\subsubsection{Charity Based Financing}

Charity based financing may include masque based and direct charity based financing consist of the instruments of Sadaqa, cash waqf, and zakat. Nabi, Islam, Bakar, and Nabi Showed two modes of financing profit based and charity based financing. The instruments of charity based financing are Zakat, sadaqa, waqaf, and qard-al-hasana where profit based financing includes saving products such as Wadia and Mudaraba and funds from commercial banks and other industrial sources.

- Masque Based Financing: The primary purpose of this enterprise is to finance in spreading Islamic knowledge which creates the employment opportunities for a large number of people as well as assists in establishing and operating autonomous body (e. g., Islamic Foundation) which uses the funds in turn for various social welfare activities. As the Baitul-Mukarram complex is providing funds to Islamic Foundation $^{1}$ in various activities relating to social welfare, it helps by organizing multiple literacy programs, spreading fundamental Islamic knowledge (Mohiuddin, 2017).

- Direct Charity Based Financing: Sometimes the beneficiaries receive cash funds, foods as well as clothes directly from the donors. The Islamic financial institutions provide cash, grains, and other commodities in different Religious festive through sadaqa, cash waqf, and zakat. In addition to they

\footnotetext{
${ }^{1}$ an autonomous body under the ministry of religious affairs in Bangladesh
} 
contribute their funds as sadaqa to the people affected by natural disasters and developmentally disabled people of the society which also assists in achieving SDGs.

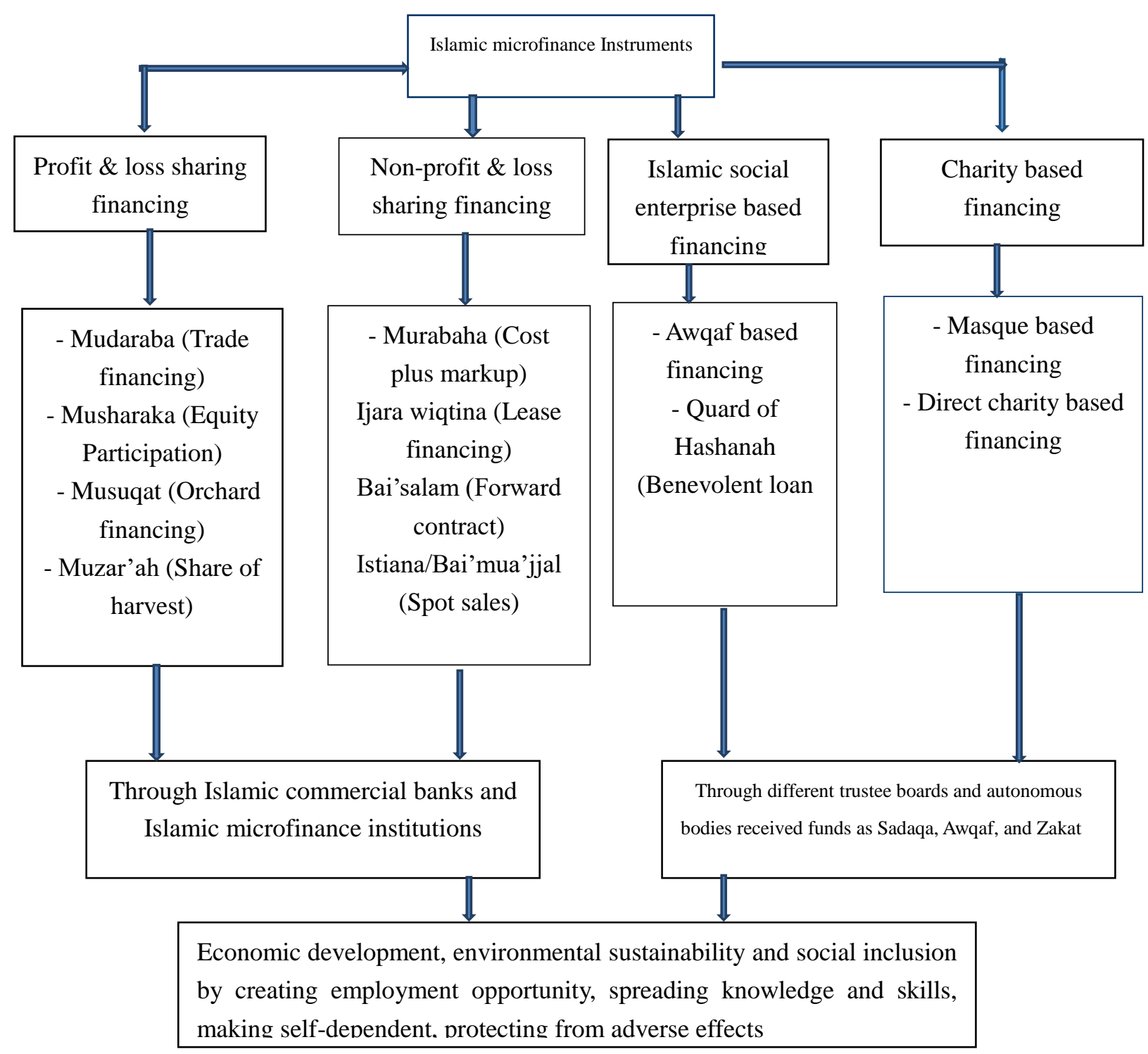

Figure 1: Islamic Micro-finance Conceptual Model to achieve SDG

\subsection{The Scenario of Islamic Microfinance Institutions in Bangladesh}

Before starting the discussion on Islamic Microfinance institutions and their contributions on attaining SDGs especially for poverty alleviation, we can get a glimpse of conventional microfinance institutions in Bangladesh. Bangladesh is leading in microfinance institutions. It has large numbers of NGOs that are involved in giving collateral-free credit to the poor and ultra-poor people. By providing microcredit, these NGOs have been able to reduce poverty of millions of families through generations of own-oriented employment over the last couple of years. Microfinance institutions in Bangladesh gained pace after establishing the microcredit regulatory authority in 2006. The microfinance development in Bangladesh in recent years is summarized in table 1. From the table 1, although the numbers of licensed NGO-MFIs are increasing in current years, no of branches, employees, clients, 
and even borrowers are stagnated with little bit fluctuation from 2010 to 2015 .

Table 1: Development of microfinance in Bangladesh

\begin{tabular}{lllllll}
\hline Particulars & $\mathbf{2 0 1 0}$ & $\mathbf{2 0 1 1}$ & $\mathbf{2 0 1 2}$ & $\mathbf{2 0 1 3}$ & $\mathbf{2 0 1 4}$ & $\mathbf{2 0 1 5}$ \\
\hline $\begin{array}{l}\text { No. of Licensed NGO- } \\
\text { MFIs }\end{array}$ & 516 & 576 & 590 & 649 & 676 & 697 \\
\hline No. of Branches & 17,252 & 18,066 & 17,977 & 14,674 & 14,730 & 15,609 \\
\hline No. of Employees & 109,597 & 111,828 & 108,654 & 110,734 & 109,628 & 110,781 \\
\hline No. of Clients (million) & 25.28 & 26.08 & 24.64 & 24.6 & 25.11 & 26.00 \\
\hline $\begin{array}{l}\text { No. of Borrowers } \\
\text { (million) }\end{array}$ & 19.21 & 20.65 & 19.31 & 19.27 & 19.42 & 20.35 \\
\hline
\end{tabular}

Source: MRA-MIS Database (Microcredit Regulatory Authority [MRA], 2015).

\subsubsection{Current Scenario of Islamic Microfinance in Bangladesh}

Total Islamic microfinance clients in the whole world are approximately 1 million, more than half of them are in Bangladesh, and over 80 percent of them are involved in Bangladesh, Indonesia, and Afghanistan. Islamic microfinance market comprises by 6 Islamic banks, 20 small Islamic microfinance institutions (IMFIs) and Islamic microfinance program of a conventional MFI. Association of Muslim Welfare Agencies in Bangladesh (AMWAB) works as a wholesale fund provider to a limited scale. Islamic banks are regulated by Bangladesh Bank, Central Bank of Bangladesh while Islamic microfinance institutions (IMFs) have licenses from Micro Credit Regulatory Authority (MRA), the watchdog of microfinance in Bangladesh. Islami Bank Bangladesh Limited (IBBL), the first Islamic bank in South Asia is the largest provider of Islamic microfinance in Bangladesh accounting for 78.84 percent share of Islamic microfinance market (Nabi et al.). Islamic microfinance institutions in Bangladesh usually use deferred-payment sales (bay mu'ajjal) mode of financing that is facing a heavy competition with conventional NGO from Table 2: Scenario of Islamic Microfinance in Bangladesh (2015)(Dhaoui, 2015).

Table 2: Scenario of Islamic Microfinance in Bangladesh (2015)

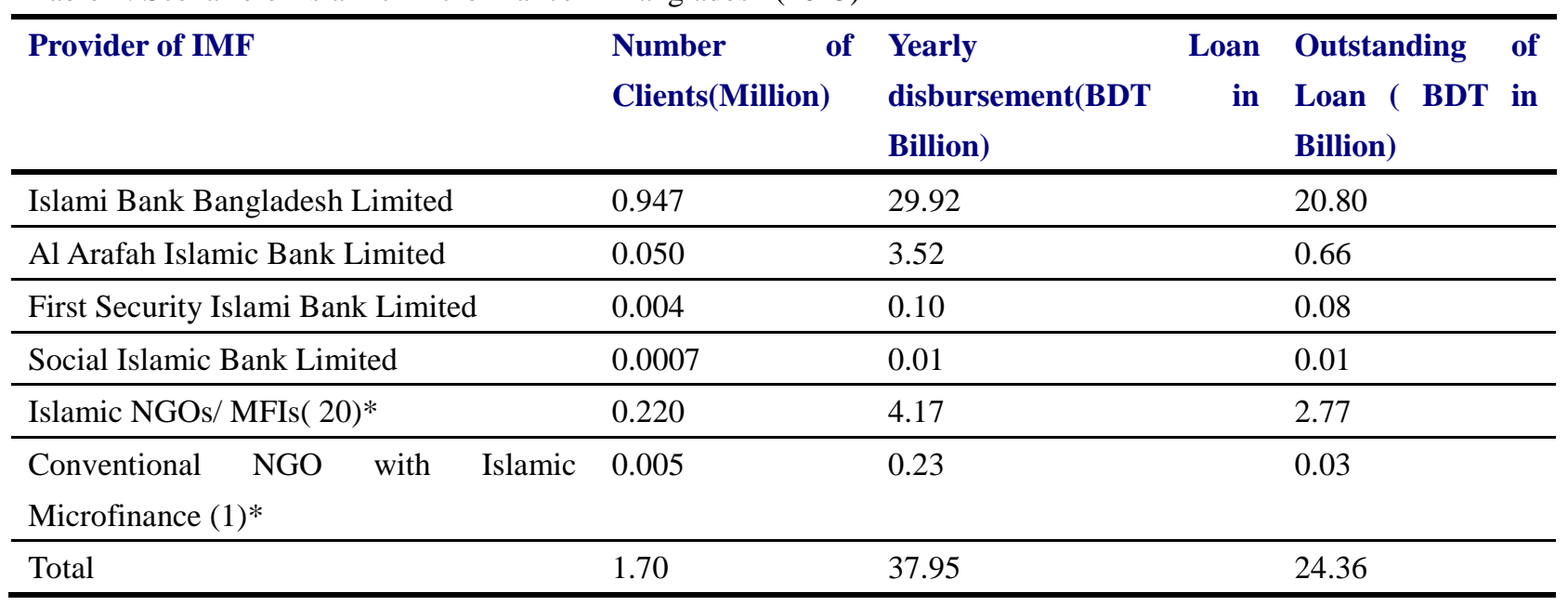

Source: (i) Respective Islamic banks, (ii) Association of Muslim Welfare Associations Bangladesh (AMWAB) and (iii) TMSS- Only conventional NGO with Islamic microfinance program. * Provisional data

\subsubsection{Performance of Rural Development Scheme up to 2015}

Islami Bank Bangladesh Limited launched its journey of Rural Development Scheme in 1995. In the meantime, $304+$ branches of the bank have been performing their activities of the scheme in their respective areas. About 18 , 
615 villages have been covered by the scheme were 9, 47,305 members have been involved. The members have been provided investment facilities an amount of BDT 1, 30,445.12 million having outstanding BDT 20,798.82 million where members saving is BDT 6,490. The recovery rate of the scheme is approximately $99.59 \%$

Table 3: Performance of Rural Development Scheme in Bangladesh

\begin{tabular}{lll}
\hline Sl. & Area of performance & No. \& Volume/ Amount \\
\hline 01 & No. of Branches handling the scheme & $304+$ \\
\hline 02 & No. of Villages & 18,615 \\
\hline 03 & No. of members & $9,47,305$ \\
\hline 04 & Cumulative disbursement & BDT(Million) 130445.12 \\
\hline 05 & Current Outstanding & BDT(Million) 20798.82 \\
\hline 06 & Members savings & BDT(Million) 6890 \\
\hline 07 & Share in IBBL'S total investment & $3.64 \%$ \\
\hline 08 & Rate of Recovery & $99 \%$ \\
\hline 09 & No. of women members & $85 \%$ \\
\hline
\end{tabular}

Islami Bank Bangladesh Limited is offering a vast dimension in Investment arena for RDS throughout the country. Bar chart-1 displays the investment and saving scenario of IBBL that have been increasing day by day since launching the scheme. This increased investment phenomenon is contributing a lot to the up economic gradation of the poor- trodden people of the country.

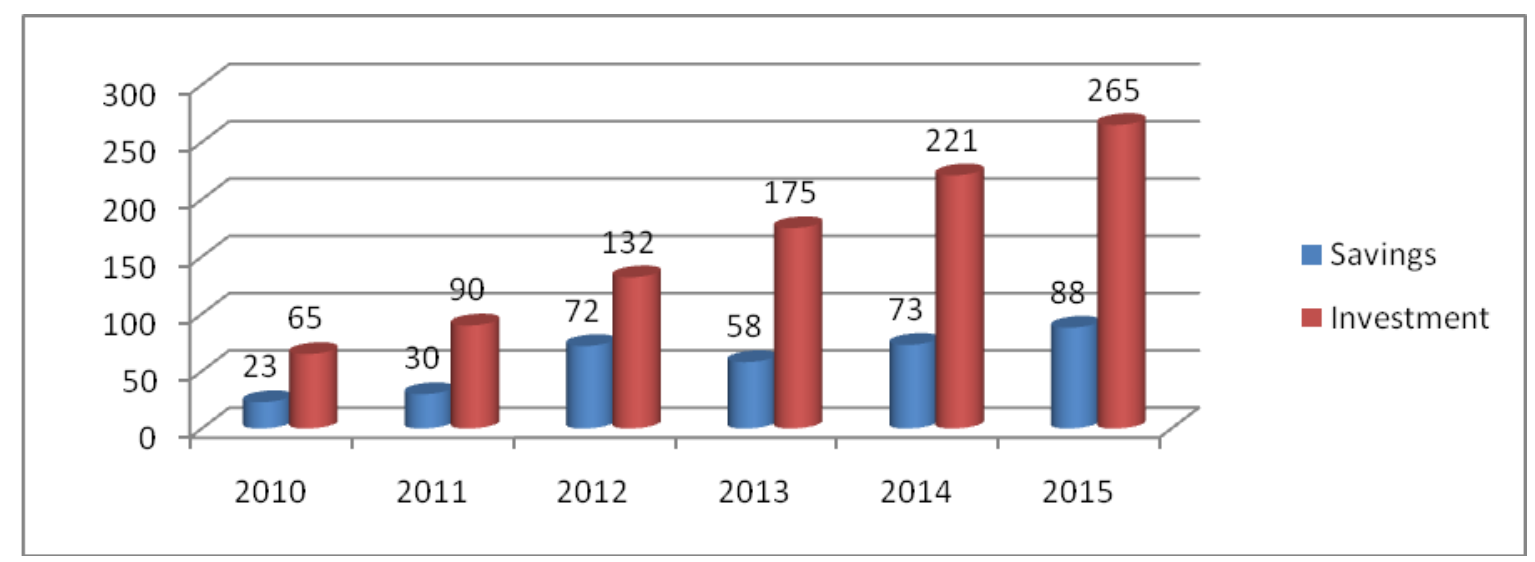

Figure 2: Trends in Savings and Investment of RDS (Million the US \$)

IBBL takes some more investment schemes as Islamic Microfinance.

- Household Durable Scheme (HDS): The primary objective of the scheme is to enhance the standard of living and quality of life by extending investment facilities to purchase household articles of the fixed income group.

- Small Business Investment Scheme (SBIS): The objective of the scheme is to help unemployed educated youths of rural and urban areas for being self -employment and provide investment to entrepreneurs and small business people.

- Agricultural Implement Investment Scheme (AIIS): Within this scheme, some important options are covered such as to provide power tillers, power pumps, thresher machines, shallow tube wells, etc. on easy terms to unemployed rural youths to be self-employed. 
- Women Entrepreneurs Investment Scheme (WEIS): The scheme fulfills three primary objectives such as 1. to extend and support the investment facilities to female entrepreneurs of different sections of the society, 2. to assist the potential not employed women to include them in the production cycle. 3 . To upgrade the socio-economic condition of rural women by expanding investment portfolio.

- Integrated Development Approach (IDA): The primary purpose of the scheme is to provide not only small investment facilities to the stakeholders but also to make sure different types of facilities \& services to the down-trodden people as a part of Integrated Development Approach along with Corporate Social Responsibility. The following points are covered under the scheme: 1. Humanitarian assistance programs, 2. The education program, 3. Capacity building program, 4. Health \& Medicare Program, 5. Environmental protection program.

- Urban Poor Development Scheme (UPDS): Some more rigorous objectives are covered by the scheme such as, 1. to improve the living condition of urban poor specially the slum dwellers, 2. to assist to alleviate urban poverty by providing investment in income generating activities, 3 . to improve the status of Health, Sanitation, education of urban poor especially the women \& children, 4. to help to improve the environmental situation of the urban poor, and 5. to reduce violence $\&$ crime by enhancing the ethical and religious values.

\subsubsection{Non- Financial Services by IBBL}

Islami Bank Bangladesh Limited is not only directly providing financial services, but some non-financial services are given to the very poor or ultra-poor to improve the overall living condition of them that are directly related with term sustainable development goals. The non-financial services (Welfare activities) are as follows:

- Relief distribution program

- Health awareness development program

- Training for the beneficiaries and Centre leaders

- Sanitation program

- Treatment assistance for the poor members

- Plantation program

- Distribution of education materials

- Scholarship award program

\subsection{The Contributions of IMFs Achieving SDGs}

The study observes in an Islamic finance sector-wise investment where the highest investment was stood at 29.49\% in the MSME (Micro, Small and Medium Enterprises) sector at the end of the quarter April-June 2016. The next position was occupied by Business \& Trade sector (27.00\%) followed by Industrial sector (23.92\%), others (8.77\%), Real Estate (7.08\%), Transportation (1.53\%), Agriculture (1.46\%), Electricity, Gas and Water supply $(0.65 \%)$ and Poverty Alleviation (0.10\%) (Bank, 2014).

\subsubsection{Poverty Reduction and End Hunger (SDG 1 and SDG 2)}

In Bangladesh with more than 160 million people, $24.8 \%$ live below the poverty line whose income less than $\$ 2$ per day. The extreme poverty rate of Bangladesh dropped to 12.9 percent (World Bank, 2016). According to Wrold Bank (2016), Bangladesh is making progress in reducing poverty rate and has a chance of overcoming the extreme poverty by 2030. The Islamic microfinance funds are spent on different types of education, training and health in Bangladesh. Islamic banks serve the deprived and retarded segments of people who live below extreme poverty through their micro-financing. Islamic financial institutions are contributing $0.10 \%$ of its total investment for poverty alleviation. Islamic banks through profit and loss sharing mode of investment including 
Zakat, waqf and charitable activities have been another alternative pathway to reduce poverty in Bangladesh (Bank, 2014). Mamun et al. (2017)mentioned that Islamic microfinance institutions through the efficient accumulation of a Zakah fund, Waqf and Sadaqah and their mobilization with the proper channel are keeping the role in addressing the desired eradication of poverty.

\subsubsection{Good health and Quality education (SDG 3 and SDG 4)}

Islamic microfinance like RDS provides education and Medicare facilities to the down-trodden people. Besides many charitable hospitals such as Ahsania Charitable cancer hospital, Islami Bank Foundation are also giving medical treatment with low costs to the poorer section of the society all over the country. The vulnerability of the poor is reduced and their socioeconomic status improved with the better health condition and the education level of their children (Bhuiyan, Siwar, Ismail, et al., 2011; Md Saad, 2010). The Islamic Foundation with 29 Islamic missions including treating 18,385,354 patients, providing literacy training to 380,038 illiterate people and supplying 2240 person with interest-free microcredit loans is working overall districts in Bangladesh (Foundation, 2015).

\subsubsection{Clean Water, Sanitation Energy, Consumption and Production (SDG 6, SDG 7 and SDG 12)}

Islamic Bank Bangladesh Limited (IBBL) established their microcredit RDS to improve the livelihood of urban poor especially the Health, sanitation \& education status of urban poor especially the children \& women and providing investment facilities with an amount of BDT 62,063.64 million to 765,011 since beginning the scheme in 1995. It also extends the investment facilities providing hand tube-wells keeping in view the needs of safe drinking water and rural housing facilities of the rural dwellers (Dhaoui, 2015). Bangladesh agriculture sector facing a lot of funding difficulties need more innovative products. Islamic microfinance such as Salaam can help the rural farmers empowering them providing loan with greater flexibility during contract period which ensures protection against certain losses (Mohiuddin, 2017).

\subsubsection{Gender Equality and Empowering Women and Girls (SDG 5)}

It also plays a vital role in the empowerment of the poor people especially women towards developing their micro enterprises (Omar, Noor, \& Dahalan, 2012).

\subsubsection{Sustainable Economic Growth and Employment Opportunity (SDG 8)}

The IMF has shown the power and success in achieving the accelerated economic growth of their microcredit with reaching the rural poor people. Besides, it enhances career growth with the significant increase in firm performance especially entrepreneurial values and management practices (Mahmood \& Mohd Rosli, 2013; Shirazi, 2012)

\subsubsection{Infrastructure and Human Safety (SDG 9 And 11)}

Islamic Microfinance empowerment has been regarded as an important tool for improving the household's quality of life regarding better and bigger houses and healthy conditions (bin Mohamad, 2013; A. Usman, Tasmin, Ulum, \& AA, 2016)

\subsubsection{Peace, Justice and Global Partnership for Sustainable Development}

Zakat and Awqaf regulated by separate ordinances are not capable to solve "social problem. Hence IMFs such as the "Urban Poor Development Scheme (UPDS)" of IBBL established to develop welfare oriented banking system and to ensure equity and justice in the field of all economic activities is also trying to reduce the level of crime \& violence through the development of ethical and religious values through its microfinance (Dhaoui, 2015).

5.3.8 Combating Climate Change, Ocean Resources, Managing Land and Forest (SDG 13, SDG14 and SDG 15) With increasing the global awareness, the microfinance institutions are considering the environmental, social and governance (ESG) issues during their decision-making process (Caplan, 2013). The ESG goals highly depend on 
the steps adapted which are taken in their activities(Ahmed et al., 2015).

6. Conclusion and Policy Implication

The prime target of this study is to examine the impact of Islamic Microfinance in achieving very recent phenomenon called Sustainable Development Goals in the soil of Bangladesh. To show the role of Islamic microfinance in achieving SDGs, the study applies the existing knowledge and literature along with new modes and model of IMFs.The study also analyzes the contribution of Islamic microfinance to the economy of Bangladesh. While profit-driven conventional microfinance institutions fail to serve the needs of the poor in the manner to which they require, morally- and socially-driven Islamic microfinance can reach to the cause of problems of not only poverty-related SDGs but also in deep-rooted social services improvement in an efficient way. Islamic Microfinance Institutions are wholeheartedly working to improve the socioeconomic condition of the especially rural people that are related to goals of sustainable development.

The IBBL Rural Development Scheme is one of them, and it has an auspicious beginning to launch a lot of schemes such as Household Durable Scheme, Small Business Investment scheme, Women Entrepreneurs Investment Scheme, Integrated Development Approach, Urban Poor Development Scheme to enhance the living standard of the poverty-driven people. The RDS program of IBBL is a fantastic testimony to be expanded the schemes successfully throughout the country. Many other IMFIs are tirelessly working to initiate and implement many types of social services schemes by applying various modes such as Profit \& loss sharing financing, Non-Profit \& loss sharing financing, Islamic social enterprise based financing, and charity based financing. These financing instruments have a very significant relation to Economic development, environmental sustainability, and social inclusion by creating employment opportunity, spreading knowledge and skills, making self-dependent, protecting from adverse effects. Despite huge potentials, the portion of Islamic microfinance is 3-5\% of total microfinance market. The fundamental challenges faced by Bangladesh are:

(i) Absence of proper Guidelines for Islamic Microfinance from Microcredit Regulatory Authority; (ii) absence of sufficient Islamic microfinance institutions; (iii) Paucity of training human resources; (iv) lack of motivation from Islamic bank management (v) absence of self-oriented supportive guidelines from Central bank of Bangladesh and, (vi) absence of suitable instruments. The following recommendations can be adapted to promote Islamic microfinance industry in Bangladesh: (i) MRA can issue proper guidelines on IMFIs covering all aspects including risk management, capital adequacy, auditing, and monitoring by establishing separate department at MRA. MRA can strictly work for supervising IMFIs, as well as Shariah advisory board investigates Shariah compliances; (ii) Undertake proper measures for loan disbursement, liquidity and risk management to ensure sustainability of Islamic microfinance; (iii) Develop specific steps for providing smooth supply of funds from charity based sectors as well commercial areas with more engagement of Islamic banks; (iv) Adopt programs to develop devoted and skilled human resources and promote more efforts to train Islamic MFI manager and staffs (Khaled, M., 2011). To the end, policymakers, practitioners, academicians, Islamic NGOs, Islamic Bankers and all categories of philanthropists can work to build a vibrant Islamic Microfinance market not only for linking with sustainable development goals but also for establishing a caring society based on equity and justice. Lack of adequacy of data is a fundamental limitation of IMFIs. Future research may take initiatives to ask the questions on what extent of Islamic operation in Islamic microfinance, on operational efficiency and 
sustainability of Islamic Microfinance, on regulatory sufficiency and comprehensive comparison with the multidimensional role of indices.

\section{References}

Abul Rahman, A. R. (2007). Islamic Economics: Theoretical and Practical Perspectives in a Global Context. Islamic Microfinance: A Missing Component in Islamic Banking.

Abdul Rahman, R., \& Dean, F. (2013). Challenges and solutions in Islamic microfinance. Humanomics, 29(4), 293-306.

Ahmed, H. (2004). Frontiers of Islamic Banks: A Synthesis of the Social Role and Microfinance. Munawar Iqbal Islamic Banking in Practice 10 Said M. Elfakhani, Yusuf M. Sidani and Omar A. Fahel An Assessment of the Performance of Islamic Mutual Funds 39 Obiyathulla Ismath Bacha Value Preservation through Risk Management A Shariah Compliant Proposal for Equity Risk, 118.

Ahmed, H., Mohieldin, M., Verbeek, J., \& Aboulmagd, F. W. (2015). On the sustainable development goals and the role of Islamic finance.

Akhter, W., Akhtar, N., \& Jaffri, S. K. A. (2009). Islamic micro-finance and poverty alleviation: A case of Pakistan. Proceeding of the 2 nd CBRC, Lahore.

Al Mamun, A., Adaikalam, J., \& Abdul Wahab, S. (2012). Investigating the Effect of Amanah Ikhtiar Malaysia's Microcredit Program on Their Clients Quality of Life in Rural Malaysia.

Bank, B. (2014). Development of Islamic Banking in Bangladesh, April-June, 2014. Dhaka, Bangladesh. http://www. bangladesh-bank. org/pub/quarterly/islamic_banking/apr_jun_2014.pdf.

Bank, W. (2016).

http://www.worldbank.org/en/news/press-release/2016/10/03/bangladesh-can-overcome-extre me-poverty-through-more-inclusive-growth

Bank, w. (2016).

https://bdnews24.com/economy/2016/10/03/bangladesh-s-extreme-poverty-rate-drops-to-12.9-percent-s ays-world-bank.

Bhuiyan, A. B., Siwar, C., Ismail, A. G., \& Talib, B. (2011). Islamic microcredit is the way of alternative approach for eradicating poverty in Bangladesh: A review of Islami bank microcredit scheme. Australian Journal of Basic and Applied Sciences, 5(5), 221-230.

Bhuiyan, A. B., Siwar, C., \& Rashid, M. (2011). ISLAMIC MICROCREDIT IN BANGLADESH. The Global Journal of Finance and Economics, 8(1), 1-21.

Bin Mohamad, M. R. (2013). The Role of Entrepreneurial Competencies as a mediator in the relationship between Microfinance and Small Business Growth. Journal of Entrepreneurship and Business, 1(1), 21-31.

Buiter, W. H., \& Rahbari, E. (2015). Why Economists (and Economies) Should Love Islamic Finance. Journal of King Abdulaziz University: Islamic Economics, 28(1), 139-162.

Caplan, G. (2013). An approach to community mental health (Vol. 3): Routledge.

Davis, F. D., \& Venkatesh, V. (2004). Toward pre-prototype user acceptance testing of new information systems: implications for software project management. IEEE Transactions on Engineering Management, 51(1), 31-46.

Dhaoui, E. (2015). The role of Islamic Microfinance in Poverty Alleviation: Lessons from Bangladesh Experience.

Dossey, L. (2007). The peasant and the professor: on trust, microcredit, and world poverty. Explore The Journal of Science and Healing, 3(5), 433-444. 
Fernandez, A. (2010). Microcredit and Women's Outward Mobility in Rural Bangladesh: A Study of the Grameen Bank.

Foundation, I. (2015). Islamic Mission, Bangladesh Islamic Foundation

Hassan, M. K., \& Tufte, D. R. (2001). The x-efficiency of a group-based lending institution: The case of the Grameen Bank. World Development, 29(6), 1071-1082.

Hopwood, B., Mellor, M., \& O'Brien, G. (2005). Sustainable development: mapping different approaches. Sustainable development, 13(1), 38-52.

Hussain, M., Shahmoradi, A., \& Turk, R. (2016). An overview of Islamic finance. Journal of International Commerce, Economics, and Policy, 7(01), 1650003.

Karim, L. (2008). Demystifying micro-credit: the Grameen Bank, NGOs, and neoliberalism in Bangladesh. Cultural Dynamics, 20(1), 5-29.

Kates, R. W., Parris, T. M., \& Leiserowitz, A. A. (2005). What is sustainable development? Goals, indicators, values, and practice. Environment(Washington DC), 47(3), 8-21.

Khan, A. A., \& Phillips, I. (2010). The influence of faith on Islamic microfinance programmes. Islamic Relief Worldwide.

Laila, T. (2010). Islamic Microfinance for Alleviating Poverty and Sustaining Peace. Paper presented at the World Universities Congress, Canakkale, Onsekiz Mart University, Turkey.

Lawal, I. M., \& Imam, U. B. Islamic Finance; A Tool For Realizing Sustainable Development Goals (SDG) In Nigeria.

Mahmood, R., \& Mohd Rosli, M. (2013). Microcredit position in micro and small enterprise performance: the Malaysian case. Management research review, 36(5), 436-453.

Mamun, A., Uddin, M. R., \& Islam, M. T. (2017). An Integrated Approach to Islamic Microfinance for Poverty Alleviation in Bangladesh. Üniversitepark Bülten| University Park Bulletin.

Md Saad, N. (2010). Achieving human development objectives through microfinance institution: the case of Amanah Ikhtiar Malaysia. Journal of Islamic Economics, Banking, and Finance, 6(2), 65-78.

Mohiuddin, M. F. (2017). Islamic social enterprises in Bangladesh: Conceptual and institutional challenges. Cogent Business \& Management, 4(1), 1305674.

Nabi, M. G., Islam, M. A., Bakar, R., \& Nabi, R. Islamic Microfinance As a Tool of Financial Inclusion in Bangladesh.

Obaidullah, M., \& Khan, T. (2008). Islamic microfinance development: Challenges and initiatives.

Omar, M. Z., Noor, C. S. M., \& Dahalan, N. (2012). The economic performance of the Amanah Ikhtiar Malaysia rural microcredit programme: A case study in Kedah. The world, 2(5).

Parveen, J. A. (2009). Sustainability Issues Of Interest-Free Micro-Finance Institutions In Rural Development And Poverty Alleviation. The Bangladesh Perspective. Theoretical and Empirical Researches in Urban Management, 4(2 (11), 112-133.

Shirazi, N. S. (2012). Targeting and Socio-Economic Impact of Microfinance: A Case Study of Pakistan. Islamic Economic Studies, 20(2), 1-28.

Uddin, H., \& Barai, M. K. (2016). Islamic Microcredit: The Case of Bangladesh. Journal of Accounting, 6(1), 49-64.

Usman, A., Tasmin, R., Ulum, Z., \& AA, A. (2016). The Role of Islamic Micro-Finance in Enhancing the Wellbeing of the Clients: Exploratory Factor Analysis. INNOVATION AND MANAGEMENT, 1835. 
Usman, A. S., \& Tasmin, R. (2016a). The Relevance of Islamic Micro-finance in achieving the Sustainable Development Goals. International Journal of Latest Trends in Finance and Economic Sciences, 6(2), 1115-1125.

Usman, A. S., \& Tasmin, R. (2016b). The Role of Islamic Micro-finance in Enhancing Human Development in Muslim Countries. Journal of Islamic Finance, 5(1), 53-62.

\section{Copyrights}

Copyright for this article is retained by the author(s), with first publication rights granted to the journal.

This is an open-access article distributed under the terms and conditions of the Creative Commons Attribution License (http://creativecommons.org/licenses/by/4.0/). 